\title{
Practice across borders: What is the standard approach to assessment of an unprovoked seizure in an adult?
}

Nitin K. Sethi, MD, New York-Presbyterian Hospital, New York: After reading the standard approach to assessment of first unprovoked seizure in an adult in the United States, Brazil, and India (3 very different countries on 3 very different continents), one quickly realizes that there is no standard approach after all. ${ }^{1}$ Yes, the approach is somewhat "standard" when one considers tertiary care neurology centers (comprehensive epilepsy centers) around the world, but after that, all bets are off. The varying standards around the world toward assessment and management of first unprovoked seizure in an adult underscore the importance of developing and reinforcing the minimum standards that need to be met when evaluating such a patient. All patients warrant an evaluation by a physician, preferably one skilled in neurosciences, a routine awake and sleep EEG (20-40 minute study), and a CT scan. This is the message that needs to go out from organizations such as the World Federation of Neurology, the American Academy of Neurology, and the International League Against Epilepsy to the governments of these diverse countries.

Disclosures: N. Sethi is an Associate Editor for The Eastern Journal of Medicine.

Correspondence to: sethinitinmd@hotmail.com

Author Responds: Gregory D. Cascino, MD, FAAN, Mayo Clinic, Rochester, MN: I would agree with the comments of Dr. Sethi on the importance of requiring a minimal evaluation of the individual with a first unprovoked seizure, even in resource-poor countries. Improving the care of these patients should be a priority because of the potential for a treatable underlying disorder. It would be ideal for the patient to be evaluated by a neurologist; however, this is not possible in selected areas of the world because of the lack of trained medical personnel. Ideally, all patients should see a neurologist, and undergo an appropriate EEG study and structural neuroimaging procedure. As discussed in the article regarding the management of patients in India, a CT head scan may be the only imaging study available. The "standards" of the evaluation of the unprovoked seizure in the adult would be different in resource-rich countries because of the availability of neurologists and MRI studies.

Disclosures: See original article for full disclosure list.

Correspondence to: gcascino@mayo.edu

Author Responds: Andre Palmini, MD, PhD, Porto Alegre, Brazil: We appreciate the opinion of Dr. Sethi about the series of articles on the standard approach to assessment of a first unprovoked seizure in an adult. He rightly points out that whereas the United States, Brazil, and India are very different countries, the approach in tertiary centers does not differ much.

The delicate task we were asked from the editors of Neurology: Clinical Practice ${ }^{\circledR}$ was to expose the disparity of care in our countries. Rather than position papers, these were meant to describe what really happens. As such, it was not surprising that management is similar in tertiary centers, as enough data are available to formulate a basic algorithm. However, we also felt obliged to mention that limitations in the availability of and access to appropriate care often led to less than ideal approaches. 
Access to well-trained physicians, EEG, and CT scan in the acute stage following the seizure should be the universal goal. Perhaps even more than reinforcing minimum standards, however, professional societies and global institutions could envisage concerted initiatives within each country to reduce the gap between patients and good standards of care.

Disclosures: See original article for full disclosure list.

Correspondence to: apalmini@uol.com.br

1. Cascino GD, Palmini A, Radhakrishnan K, Rathore C, Menon R. What is the standard approach to assessment of an unprovoked seizure in an adult? Neurol Clin Pract 2012; 294-298.

\section{Resisting EHR}

Britt Talley Daniel, MD, Dallas, TX: As a neurologist who is resisting electronic health records, I read with interest an opinion piece published in The Wall Street Journal on September 18, 2012, entitled "A major glitch for digitized health-care records" by Soumerai and Koppel. ${ }^{1}$ The authors describe the software sold by health information technology firms for health care information technologies, known as electronic health records (EHR), as being "clunky, frustrating, user-unfriendly and inefficient." They report on a comprehensive evaluation of the scientific literature which has "confirmed what many researchers suspected: The savings claimed by government agencies and vendors of health IT are little more than hype."

The authors stated that " $[\mathrm{w}] \mathrm{ith}$ a few isolated exceptions, the preponderance of evidence shows that the systems had not improved health or saved money." "It is already common knowledge in the health-care industry that a central component of the proposed health IT system — the ability to share patients' health records among doctors, hospitals, and labs- has largely failed. The industry could not agree on data standards-for instance on how to record blood pressure or list patients' problems."

I have heard numerous stories in the hospital where I practice of physicians staying up late at night working with these electronic systems and how frustrating and difficult they are, and I would like to get Congress to change this law.

I would be glad to hear from any interested neurologists about this problem.

Disclosures: B. Daniel is on the speakers' bureau for Imax.

Correspondence to: btdaniel@aol.com

Editors Respond: Thank you for outlining your thoughts on EHRs; your concerns are widely shared. While there is undoubted value to having a record accessible from any computer or other electronic device, there is a steep learning curve. And no system is perfect. Given that penalties may come if we do not use EHRs, they are likely in our future, for better or worse. An article in this issue of Neurology: Clinical Practice adds to the ongoing debate on this important topic.

1. Soumerai S, Koppel R. A major glitch for digitized health-care records: savings promised by the government and vendors of information technology are little more than hype. The Wall Street Journal. Available at: http://online.wsj.com/article/SB10000872396390443847404577627041964831020.html. Accessed October 12, 2012. 


\title{
Neurology ${ }^{\circ}$ Clinical Practice
}

\author{
Practice across borders: What is the standard approach to assessment of an \\ unprovoked seizure in an adult? \\ Nitin K. Sethi, Gregory D. Cascino, Andre Palmini, et al. \\ Neurol Clin Pract 2013;3;88-89 \\ DOI 10.1212/CPJ.0b013e31828ee67f
}

This information is current as of April 15, 2013

$\begin{array}{ll}\begin{array}{l}\text { Updated Information \& } \\ \text { Services }\end{array} & \begin{array}{l}\text { including high resolution figures, can be found at: } \\ \text { http://cp.neurology.org/content/3/2/88.full.html }\end{array} \\ \text { Permissions \& Licensing } & \begin{array}{l}\text { Information about reproducing this article in parts (figure } \\ \text { its entirety can be found online at: } \\ \text { http://cp.neurology.org/misc/about.xhtml\#permissions }\end{array} \\ & \begin{array}{l}\text { Information about ordering reprints can be found online: } \\ \text { http://cp.neurology.org/misc/addir.xhtml\#reprintsus }\end{array}\end{array}$

Neurol Clin Pract is an official journal of the American Academy of Neurology. Published continuously since 2011, it is now a bimonthly with 6 issues per year. Copyright () 2013 American Academy of Neurology. All rights reserved. Print ISSN: 2163-0402. Online ISSN: 2163-0933.

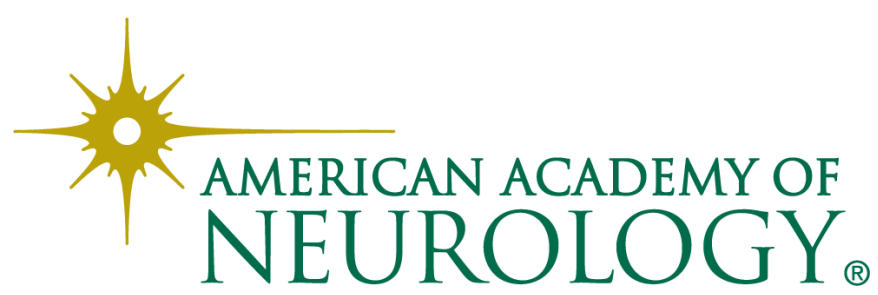

